\title{
Evidence-Based Advances in Transfusion Practice in Neonatal Intensive Care Units
}

\author{
Robert D. Christensen ${ }^{\mathrm{a}}$ Patrick D. Carroll ${ }^{\mathrm{a}}$ Cassandra D. Josephson ${ }^{\mathrm{b}, \mathrm{c}}$

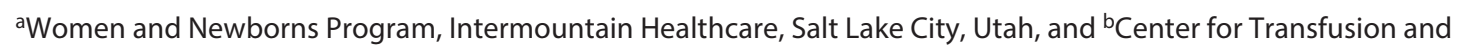 \\ Cellular Therapies, Emory University School of Medicine, and 'Aflac Cancer Center and Blood Disorders Services, \\ Children's Healthcare of Atlanta, Atlanta, Ga., USA
}

\section{Key Words \\ Erythrocytes · Fresh-frozen plasma · Platelets · Transfusion}

\begin{abstract}
Background: Transfusions to neonates convey both benefits and risks, and evidence is needed to guide wise use. Such evidence is accumulating, but more information is needed to generate sound evidence-based practices. Objective: We sought to analyze published information on nine aspects of transfusion practice in neonatal intensive care units. Methods: We assigned 'categories of evidence' and 'recommendations' using the format of the United States Preventive Services Task Force of the Agency for Healthcare Research and Quality. Results: The nine practices studied were: (1) delayed clamping or milking of the umbilical cord at preterm delivery - recommended, high/substantial $A_{;}$(2) drawing the initial blood tests from cord/placental blood from very low birth weight (VLBW, $<1,500 \mathrm{~g}$ ) infants at delivery - recommended, moderate/moderate $B$; (3) limiting phlebotomy losses of VLBW infants - recommended, moderate/substantial B; (4) selected use of erythropoiesis-stimulating agents to prevent transfusions - recommended, moderate/moderate-moderate/small B, C; (5) using platelet mass, rather than platelet count, in platelet transfusion decisions - recommended, moderate/small C; (6) permitting the platelet count to fall to $<20,000 / \mu \mathrm{l}$ in 'stable' neonates before transfusing platelets - recommended, low/small I; (8) permitting the platelet count to fall to $<50,000 / \mu \mathrm{l}$ in 'unstable' neonates be-
\end{abstract}

\section{KARGER}

E-Mail karger@karger.com

www.karger.com/neo fore transfusing platelets - recommended, moderate/small $C$, and (9) not performing routine coagulation test screening on every VLBW infant - recommended, moderate/small C. Conclusions: We view these recommendations as dynamic, to be revised as additional evidence becomes available. We predict this list will expand as new studies provide more information to guide best transfusion practices.

(c) 2014 S. Karger AG, Basel

\section{An Evidence Base to Inform and Continually Improve Transfusion Practice in Neonatal Intensive Care Units}

Like many aspects of clinical neonatology, transfusion practice in neonatal intensive care units (NICUs) originated largely as an extrapolation from pediatric and adult practice, which then evolved by experience and reason, not by traditional clinical trials methods [1]. In current neonatology practice, when a transfusion is contemplated, the neonatologist will generally contextualize the best treatment by integrating his/her own past clinical experiences with information recently acquired from reliable sources [2-7]. However, progress toward better outcomes and cost containment requires that this process be replaced by a new paradigm of evidence-based decision making [1].

In this review, we update readers on what we judge to be the best evidence for nine aspects of red blood cell (RBC), platelet and plasma transfusions in the NICU.
(C) 2014 S. Karger AG, Basel

1661-7800/14/1063-0245\$39.50/0
Dr. Robert D. Christensen

Women and Newborns Program, Intermountain Healthcare 4401 Harrison Boulevard

Ogden, UT 84403 (USA)

E-Mail rdchris4@ihc.com 
Table 1. Methods for grading evidence and formulating a recommendation based on the techniques used by the US Preventive Services Task Force, US Department of Health and Human Services' Agency for Healthcare Research and Quality [8]

\begin{tabular}{ll}
\hline \multicolumn{2}{l}{ Category of evidence } \\
\hline 1A & Meta-analysis of randomized clinical trials \\
1B & At least one randomized clinical trial \\
2A & At least one controlled study without randomization \\
2B & At least one quasi-experimental study \\
3 & Descriptive studies, such as comparative, correlation or \\
& case-control studies \\
4 & $\begin{array}{l}\text { Expert committee reports or opinions and/or clinical } \\
\text { experience of respected authorities }\end{array}$
\end{tabular}

\begin{tabular}{lllll}
\hline \multicolumn{2}{l}{$\begin{array}{l}\text { Recommendation } \\
\text { Certainty of } \\
\text { net benefit }\end{array}$} & \multicolumn{4}{l}{ Magnitude of net benefit } & & \\
\cline { 2 - 5 } & substantial & moderate & small & zero/negative \\
\hline High & A & B & C & D \\
Moderate & B & B & C & D \\
Low & I & & & \\
\hline
\end{tabular}

Certainty of benefit is judged as high when consistent results are found from well-designed, well-conducted studies in representative populations. Moderate indicates evidence of a likely benefit but confidence in the estimate of effect size is diminished by few or inadequate studies. More information is needed. Low indicates insufficient evidence to assess an effect on health outcomes.

Magnitude of benefit is judged by statistics such as number needed to treat, number needed to screen, and number treated to result in 1 adverse health event. The last category, $\mathrm{D}$, indicates that the recommendation, if enacted, is expected to achieve no net benefit or to result in overall harm.

Readers will glean from the evidence we present that our recommendations are derived from a scant literature, thus many of our recommendations may be controversial. Also, our recommendations are not comprehensive, only examining specific aspects of transfusion that have recently been subjected to study and peer review. As the NICU transfusion evidence base expands, the number of recommendations will increase, along with an increase in the level of certainty that the recommendations are sound. Perhaps in time, a comprehensive list of NICU transfusion recommendations will evolve and become adopted by various organizations as practice standards, whereas the recommendations we present here must be recognized as preliminary and dynamic.

The methodology and terminology we used in assembling this review are those used by the United States Preventive Services Task Force, a panel of physicians and epidemiologists commissioned by the Agency for Health- care Research and Quality of the US Department of Health and Human Services [8]. In keeping with the directive of the Task Force, we attempted to draw each recommendation from comprehensive analyses with attention to the quality of the published studies. Table 1 summarizes the Task Force's methods for determining the categories of evidence and the methods for assigning strength of recommendations.

\section{RBC Transfusion}

\section{Delayed Cord Clamping or Cord Milking at Preterm Delivery}

Historically, the routine delivery process involved delayed clamping/tying and cutting of the umbilical cord. Over several centuries, this practice has morphed into one where immediate cord clamping has become standard practice. It has been suggested that immediate cord clamping was adopted as a consequence of developing a medical cord clamp, theories about preventing erythroblastosis fetalis and about placental blood as a new source of transfusion blood, and introducing the Apgar score [9]. This practice of immediate cord clamping became standard practice without any studies showing it was more beneficial than the previous practice of delayed cord clamping. In fact, scientists throughout the years have cautioned against immediate cord clamping. Over 200 years ago, Erasmus Darwin stated, 'Another thing very injurious to the child is the tying and cutting of the navel string too soon; which should always be left till the child has not only repeatedly breathed but till all pulsation in the cord ceases. As otherwise the child is much weaker than it ought to be, ...' [10].

Studies over 40 years ago demonstrated increased fetal blood volume and decreased placental blood volume as a result of both delaying cord clamping up to $180 \mathrm{~s}$ and the position of the infant relative to the mother in both vaginal and cesarean delivery [11-13] (table 2). Recently, benefits of delayed versus immediate cord clamping have been assessed in premature infants. By 2004, there were at least seven randomized controlled trials comparing immediate with delayed cord clamping in preterm infants. Although the definition for delayed cord clamping varied from 30 to $120 \mathrm{~s}$, delayed cord clamping was associated with higher hematocrits $4 \mathrm{~h}$ after birth, 50\% fewer transfusions for anemia or hypotension, and less intraventricular hemorrhage (IVH) [14]. While some were studying delayed cord clamping, others were investigating umbilical cord milking as a more rapid alternative $[15,16]$. By 
Table 2. Effect of the relative position of the infant during delayed cord clamping and duration of delayed cord clamping on fetal and residual placental blood volumes

\begin{tabular}{|c|c|c|c|c|}
\hline \multirow[t]{2}{*}{ Infant position } & \multirow{2}{*}{$\begin{array}{l}\text { Time of delayed } \\
\text { clamping, s }\end{array}$} & \multicolumn{2}{|c|}{ Blood volume } & \multirow[t]{2}{*}{ First author (year) } \\
\hline & & fetus, $\mathrm{ml} / \mathrm{kg}$ & placenta, $\mathrm{ml} / \mathrm{kg}$ & \\
\hline \multicolumn{5}{|l|}{ Vaginal } \\
\hline Neutral & 5 & 70 & 35 & Yao [11] (1969) \\
\hline Neutral & 180 & 93 & 12 & \\
\hline $40 \mathrm{~cm}$ above introitus & 180 & $\mathrm{n} / \mathrm{a}$ & 24 & Yao [12] (1969) \\
\hline $20 \mathrm{~cm}$ above introitus & 180 & $\mathrm{n} / \mathrm{a}$ & 20.5 & \\
\hline $10 \mathrm{~cm}$ below introitus & 180 & $\mathrm{n} / \mathrm{a}$ & 13.8 & \\
\hline $40 \mathrm{~cm}$ below introitus & 30 & $\mathrm{n} / \mathrm{a}$ & 16.3 & \\
\hline \multicolumn{5}{|l|}{ Cesarean section } \\
\hline & no delay & 87 & $\mathrm{n} / \mathrm{a}$ & Sisson [14] (1973) \\
\hline $15 \mathrm{~cm}$ above the abdominal wall & 180 & 67 & $\mathrm{n} / \mathrm{a}$ & \\
\hline $15 \mathrm{~cm}$ below the vagina & 180 & 106 & $\mathrm{n} / \mathrm{a}$ & \\
\hline
\end{tabular}

2012, a Cochrane review including randomized controlled trials on delayed cord clamping up to $180 \mathrm{~s}$ or umbilical cord milking versus immediate cord clamping contained fifteen studies [14]. The results demonstrated $39 \%$ fewer transfusions for anemia, $41 \%$ fewer patients with IVH and $38 \%$ fewer patients with necrotizing enterocolitis. Studies continue to investigate the optimal duration of delayed cord clamping, and debate persists regarding delayed cord clamping versus umbilical cord milking. The category of evidence for delayed clamping/ milking at premature delivery is $1 \mathrm{~A}$ and the strength of recommendation is high/substantial A (table 3).

Drawing All Initial Laboratory Blood Tests of Very

Low Birth Weight Infants using Fetal Blood in the

Cord/Placenta, Thereby Drawing No Blood Initially

from Very Low Birth Weight Neonates

Whereas term infants generally require little to no laboratory testing following birth, preterm infants may require a wide range of laboratory testing to aid in their care. The smallest infants are often among the sickest. Very low birth weight (VLBW) infants consistently experience greater phlebotomy blood loss on the 1st day of life than on any other day during their hospitalization [17]. The laboratory studies performed on admission can require up to $10 \%$ of an infant's circulating blood volume.

Obtaining admission laboratory studies from the otherwise discarded fetal blood in the umbilical cord or placenta is an alternative to drawing admission laboratory studies from the infant. In paired samples, complete blood count and manual differential count are clinically equivalent $[18,19]$. Blood culture results from umbilical cord segments or fetal vessels on the placenta have been investigated in several studies [17-23]. This method offers the benefit of increased blood culture volume, thereby increasing the sensitivity of the blood culture [24,25]. Care must be given to adequately sterilize the field prior to obtaining blood cultures just as when obtaining blood cultures from other sites. Neonatal blood type and screen is widely accepted when obtained from umbilical cord blood $[26,27]$. Some states recommend drawing the newborn metabolic screening tests of VLBW infants before antibiotics are started, blood products are transfused or amino acid-containing hyperalimentation solutions are administered, and in many cases this is upon admission to the NICU. Obtaining this first sample from the umbilical cord or placenta will result in similar limitations as an admission sample obtained directly from the infant. In both scenarios, repeat testing is required.

The practice of obtaining the admission laboratory studies from otherwise discarded fetal blood in the umbilical cord or placenta decreases the rate of RBC transfusions in VLBW infants [12,28]. However, to date, this has not been tested in randomized controlled trials and thus the category of evidence is $2 \mathrm{~B}$ with a strength of recommendation of moderate/moderate $\mathrm{B}$.

\section{A Consistent Approach to Limiting Phlebotomy Losses} of VLBW Infants in the First Days after Birth

Significant variability in phlebotomy losses has been described between different hospitals. The $10.7 \mathrm{ml} / \mathrm{kg}$ difference reported between hospitals in the first 2 weeks of life is clinically important [29]. This variability remained 
Table 3. Aspects of NICU RBC transfusion subjected to analysis

\begin{tabular}{lll}
\hline Topic & Category of evidence & Strength of recommendation \\
\hline $\begin{array}{l}\text { Delayed clamping or milking } \\
\begin{array}{l}\text { Drawing initial blood tests from } \\
\text { cord/placenta }\end{array}\end{array}$ & 1A & $\begin{array}{l}\text { High/substantial A } \\
\text { Moderate/moderate B }\end{array}$ \\
$\begin{array}{l}\text { Limiting phlebotomy losses } \\
\text { Erythropoietin/darbepoetin }\end{array}$ & 1B & $\begin{array}{l}\text { Moderate/substantial B } \\
\text { Moderate/moderate B } \\
\text { moderate/small C }\end{array}$ \\
\hline
\end{tabular}

Table 4. Comparison of the volumes of phlebotomy losses in preterm infants published in the literature

\begin{tabular}{|c|c|c|c|c|c|}
\hline Emmerson [73] (1993) & $27-33$ weeks & 24 & $0.6^{\mathrm{a}}$ & 46 & 25.8 \\
\hline Messer [74] (1993) & $<33$ weeks & 51 & $0.2^{\mathrm{a}}$ & 60 & 14.2 \\
\hline Maier [75] (1994) & $750-1,500 \mathrm{~g}$ & 241 & 0.8 & 42 & $33.6^{\mathrm{a}}$ \\
\hline Kling [32] (1997) & $<1,500 \mathrm{~g}$ & 47 & 2.3 & 7 & $16.1^{\mathrm{a}}$ \\
\hline \multirow[t]{2}{*}{ Ohls [76] (2001) } & $<1,000 \mathrm{~g}$ & 172 & $1.4^{\mathrm{a}}$ & 70 & 98.5 \\
\hline & $1,000-1,250 \mathrm{~g}$ & 118 & $0.6^{\mathrm{a}}$ & 56 & 36 \\
\hline Maier [42] (2002) & $<1,000 \mathrm{~g}$ & 219 & 0.6 & 70 & $45^{\mathrm{a}}$ \\
\hline Widness [35] (2005) & $500-1,000 \mathrm{~g}$ & 93 & $4.6^{\mathrm{a}}$ & 14 & 65 \\
\hline Haiden [77] (2006) & $450-800 \mathrm{~g}$ & 40 & $0.6^{\mathrm{a}}$ & 57 & 34.5 \\
\hline Birenbaum [78] (2006) & $<30$ weeks or $<1,500 \mathrm{~g}$ & 50 & $1.7^{\mathrm{a}}$ & 14 & $24^{\mathrm{b}}$ \\
\hline Becquet [30] (2013) & $<32$ weeks and $<1,500 \mathrm{~g}$ & 47 & 0.5 & 30 & 15.1 \\
\hline
\end{tabular}

a Data extrapolated from the study. ${ }^{b}$ Determined by laboratory-specified blood volumes, not actual measurements.

even after correction for confounding variables, including gestational age, birth weight and severity of illness. Multiple studies have demonstrated variation in phlebotomy practices as evaluated by phlebotomy losses in preterm infants [30, 31] (table 4). Many studies reporting phlebotomy losses measure these losses as a possible confounder or secondary outcome. Therefore, the quality of reporting varies significantly and may grossly underestimate the actual phlebotomy loss. One study measured the phlebotomy loss for each infant including instrumentrequired blood, blood remaining after laboratory testing and blood loss on gauze. This study reported that only $33 \%$ of phlebotomy loss was instrument required, with the remaining $67 \%$ being waste or hidden blood loss [31].

Recently, through mathematical modeling based on actual phlebotomy and transfusion data, Rosebraugh et al. [31] demonstrated among VLBW infants a $41-48 \%$ potential decrease in transfusions by eliminating excess phlebotomy loss beyond that of instrument requirements (category of evidence 2B). Kling et al. [32] demonstrated phlebotomy loss to be the most likely predictor of transfusion through regression modeling. Valieva et al. [33] replicated the association between phlebotomy loss and transfusions among a cohort of extremely low birth weight infants. A retrospective review following the introduction of bedside point-of-care testing decreased transfusions by $43 \%$ without a change in the number of tests done [34]. A randomized controlled trial which decreased phlebotomy losses by $25 \%$ in the 1 st week of life through the use of in-line blood gas and chemistry monitoring led to a 33\% decrease in RBC transfusions [35].

Decreasing phlebotomy loss appears to be perhaps the most effective means to decrease $\mathrm{RBC}$ transfusions in VLBW infants. Methods to decrease phlebotomy loss include obtaining admission laboratory testing from the placenta or umbilical cord as discussed above, in-line ar- 
terial line testing [35], breaking 'diagnostic bad habits' which lead to unnecessary phlebotomy loss [36], utilization of bedside point-of-care testing [34], and optimizing the frequency and volume of blood drawn [37]. The category of evidence for this practice is $1 \mathrm{~B}$ and the strength of recommendation is moderate/substantial $\mathrm{B}$.

\section{Administering an Erythropoiesis-Stimulating Agent}

Erythropoiesis-stimulating agents can decrease transfusions of VLBW infants. Erythropoietin a has been studied more extensively than the longer acting darbepoetin. Cochrane reviews have provided meta-analysis conclusions regarding early erythropoietin [38] defined as initiation of treatment before day 8 of life, late erythropoietin [39] defined as initiation on or after day 8 of life and early versus late erythropoietin [40]. Early erythropoietin administration was associated with a $20 \%$ decrease in one or more transfusions. More infants remained transfusion free whether receiving high- or low-dose erythropoietin and/or high- or low-dose iron. The total volume of blood transfused was $6 \mathrm{ml} / \mathrm{kg}$ less in the early erythropoietin group, and the total number of transfusions and the number of donors was less in the early erythropoietin group. The meta-analysis evaluating late erythropoietin similarly found the use of erythropoietin associated with a $34 \%$ decreased risk of receiving any transfusions, preventing any transfusions in 1 infant for every 5 treated. The total number of transfusions was decreased in the erythropoietin group by 0.78 transfusions per infant. The most recent (2014) version of the late erythropoietin review states that it does not significantly reduce or increase any clinically important adverse outcomes except for a nonsignificant trend towards an increased risk for retinopathy of prematurity [39].

Two trials have randomized infants to either early or late erythropoietin treatment $[41,42]$. When evaluated together, these trials did not demonstrate significant differences between early or late erythropoietin regarding the rate of one or more RBC transfusions [40]. Similarly, there was no statistical difference in the total volume of blood transfused or the total number of transfusions between the two administration protocols.

Recently, Ohls et al. [43] reported a randomized study comparing the effects of darbepoetin, erythropoietin or placebo on transfusion requirements. The effect on neurodevelopmental outcome was also reported recently [44]. Darbepoetin, a long-acting erythropoietin analog [45], was administered weekly while erythropoietin was administered three times each week. Compared with the placebo recipients, both the darbepoetin and erythropoi- etin recipients received fewer transfusions, fewer donor exposures and less total volume of donor blood. There were no differences in secondary outcomes, including retinopathy of prematurity. The 18- to 24-month followup study demonstrated better cognitive outcomes in those randomized to either erythropoiesis-stimulating agent than to placebo recipients [44].

Recent clinical studies suggest neuroprotective effects of erythropoiesis-stimulating agents [44, 46-49], and this is the topic of several current trials. Our conclusion is that evidence supports the selective use of erythropoietin (category of evidence 1a, strength of recommendation moderate/moderate $\mathrm{B}$ ) or darbepoetin (category of evidence $1 \mathrm{~b}$, strength of recommendation moderate/small C) to reduce transfusions in VLBW neonates. Additional research elucidating the neuroprotective effects may modify these recommendations.

\section{Prophylactic Platelet Transfusions}

Note: the topic of neonatal platelet transfusion is reviewed in detail in an accompanying report in Neonatology by Carr et al. [50], and therefore this section will be limited and focused primarily on practices in the USA.

Platelet transfusions can be lifesaving for neonates with thrombocytopenic hemorrhage [51]. However, $>95 \%$ of NICU platelet transfusions are prophylactic, meaning they are given to thrombocytopenic neonates who have no signs of bleeding, with the intent that the transfusions will prevent hemorrhagic problems [52]. The benefits of these transfusions remain speculative. However, transfusion risks are well documented, and multiple platelet transfusions compound these risks [53].

Surveys of neonatologists indicate that platelet transfusions are more restricted in central Europe [54] and given more liberally in North America [55]. However, as shown in table 5, the guidelines suggested by Stanworth et al. [56] and Venkatesh et al. [57] from England are very similar to the guidelines of Intermountain Healthcare in the western USA $[58,59]$. These advocate that a stable NICU patient would receive a platelet transfusion only if the platelet count falls below 20,000 platelets/ $\mu$, while a patient on extracorporeal membrane oxygenation or immediately before or after an operation would be transfused if the count falls below 100,000 platelets/ $\mu$ l. Using these guidelines, neonates judged as 'unstable' (more likely to have spontaneous hemorrhage) would receive a platelet transfusion only if the count falls below 50,000 platelets/ $\mu$ l. The category of evidence on which these guidelines are based 
Table 5. Guidelines for administering prophylactic platelet transfusions proposed by Venkatesh et al. [57], Stanworth et al. [56] and Intermountain Healthcare [59, 60]

\begin{tabular}{llll}
\hline Category & $\begin{array}{l}\text { Not bleeding, but on ECMO, } \\
\text { or pre- or postoperatively }\end{array}$ & $\begin{array}{l}\text { Not bleeding, not on } \\
\text { ECMO, but 'unstable' }\end{array}$ & Stable \\
\hline Trigger value for platelet transfusion & $<100,000 / \mu \mathrm{l}$ & $<50,000 / \mu \mathrm{l}$ & $<20,000 / \mu \mathrm{l}$ \\
\hline
\end{tabular}

The term 'unstable' is meant to indicate an increased risk for hemorrhage. The term is not strictly defined, but considerations include a high risk for IVH due to extreme prematurity in the 1st week after birth, undergoing invasive but not surgical procedures and treatment with medications known to adversely affect platelet function. $\mathrm{ECMO}=$ Extracorporeal membrane oxygenation.

Table 6. Aspects of NICU platelet transfusion subjected to analysis

\begin{tabular}{lll}
\hline Platelet transfusion topic & $\begin{array}{l}\text { Category } \\
\text { of evidence }\end{array}$ & $\begin{array}{l}\text { Strength of } \\
\text { recommendation }\end{array}$ \\
\hline $\begin{array}{l}\text { Platelet transfusion decisions should consider the platelet count } \\
\text { and also the patient's clinical condition }\end{array}$ & 3 & Low/small I \\
$\begin{array}{l}\text { Platelet mass, rather than platelet count, should constitute the } \\
\text { transfusion 'trigger' }\end{array}$ & $2 \mathrm{~B}$ & Moderate/small C \\
$\begin{array}{l}\text { The platelet count can be permitted to fall to } 20,000 / \mu l \text { (or a } \\
\text { platelet mass of } 160 \mathrm{fl} / \mathrm{nl}) \text { in a 'healthy' neonate }(\mathrm{a} \text { patient less } \\
\text { likely to have significant spontaneous hemorrhage) }\end{array}$ & 3 & Low/small I \\
$\begin{array}{l}\text { The platelet count can be permitted to fall to } 50,000 \mu \mathrm{l} \text { (or a } \\
\text { platelet mass of } 400 \mathrm{fl} / \mathrm{nl}) \text { in a 'sick' neonate (a patient more } \\
\text { likely to have significant spontaneous hemorrhage) }\end{array}$ & $2 \mathrm{~B}$ & Moderate/small C \\
\hline
\end{tabular}

is low quality (grades 3 and 4), meaning the evidence was obtained from expert committee reports or opinions of respected authorities. On that basis, we judge that the use of platelet count plus patient condition in the decisionmaking process is derived from category of evidence 3 , and the strength of recommendation must be graded low/ small 'I' because of the lack of data needed to assess both magnitude of effect and certainty of benefit (table 6).

'Platelet mass' is a concept that considers both the number of platelets per microliter of blood (the platelet count) and also the average platelet size $[58,59]$. The platelet count multiplied by the mean platelet volume results in the 'platelet mass'. The rationale for using platelet mass, rather than platelet count, for NICU transfusion decisions is that multiple platelet transfusions should be avoided whenever possible because of the risks involved, and neonates who have platelet counts qualifying for prophylactic transfusion might not qualify if it is recognized that they have predominantly large-sized platelets. The size and hemostatic capacity of a platelet plug is influenced by the product of platelet count and platelet size. For instance, a neonate with a platelet count of 60,000 platelets/ $\mu$ land a mean platelet volume of $8.0 \mathrm{fl}$ should be hemostatically equivalent to another neonate who has a platelet count of 40,000 platelets/ $\mu \mathrm{l}$ and a mean platelet volume of $12 \mathrm{fl}$. Therefore, if the 1st patient does not qualify for a platelet transfusion because the count is above the trigger of 50,000 platelets/ $\mu$, why would the 2 nd patient need a platelet transfusion? Not transfusing neonates like the 2nd patient forms the basis of expecting fewer platelet transfusions when platelet mass is used for the decision [58].

Two Intermountain Healthcare NICUs tested this hypothesis by using platelet count-based guidelines for 1 year, then switching to platelet mass-based guidelines the next year, and comparing specific outcomes during the two periods (table 7). The conclusion was that using platelet mass results in fewer platelet transfusions with similar bleeding outcomes [59]. This approach has not been tested in a traditional prospective randomized trial where neonates are transfused using one or the other guideline, and where caregivers are masked to the guideline used. However, Zisk et al. [60] showed the feasibility of this approach in a pilot randomized trial, concluding that a randomized trial would likely require perhaps 100 
Table 7. Comparison of bleeding outcomes when NICU platelet transfusions were based on platelet mass versus platelet count in two Intermountain Healthcare perinatal centers [59, 60]

\begin{tabular}{llllll}
\hline & $\begin{array}{l}\text { Receiving one or more } \\
\text { platelet transfusions }\end{array}$ & $\begin{array}{l}\text { IVH all } \\
\text { grades }\end{array}$ & $\begin{array}{l}\text { Pulmonary } \\
\text { hemorrhage }\end{array}$ & $\begin{array}{l}\text { Gastrointestinal } \\
\text { hemorrhage }\end{array}$ & $\begin{array}{l}\text { Cutaneous } \\
\text { hemorrhage }\end{array}$ \\
\hline Platelet count & $3.6 \%$ & $5.0 \%$ & $0.6 \%$ & $2.0 \%$ & $6.2 \%$ \\
Platelet mass & $1.9 \%$ & $4.5 \%$ & $0.7 \%$ & $1.4 \%$ & $5.3 \%$ \\
p value & $<0.002$ & 0.36 & 0.52 & 0.27 & 0.02 \\
\hline
\end{tabular}

or more patients per group. We judge that the recommendation to use platelet mass in the transfusion decision is derived from category of evidence $2 \mathrm{~B}$ and the strength of recommendation is graded moderate/small C (table 6).

Another way to approach the benefit of prophylactic platelet transfusions is to compare bleeding outcomes in NICUs that elect a higher platelet transfusion level (liberally transfusing NICUs) with NICUs that elect a lower platelet transfusion trigger (conservatively transfusing NICUs). von Lindern et al. $[61,62]$ conducted such an analysis in the Netherlands, finding the NICUs with higher platelet transfusion usage did not have lower odds of clinical hemorrhage. Studies by Sola-Visner [52], FerrerMarin et al. [63] and Venkatesh et al. [57] reported somewhat similar findings. Basically, no difference in IVH or other significant hemorrhagic complications were observed among neonates with platelet counts in the 20,00040,000 platelets/ $\mu$ l range compared with neonates whose counts were in the 40,000-60,000/ $\mu$ l range. Both studies concluded that IVH and other serious hemorrhages in neonates have a multifactorial pathogenesis, and keeping platelet counts $>50,000$ platelets/ $\mu$ l with transfusions may not be an effective way to prevent serious hemorrhages. This is the same conclusion reached by Andrew et al. [64], who conducted a randomized trial of platelet transfusions at a trigger level of 50,000 platelets/ $\mu$ in one group versus 150,000 platelets/ $\mu 1$ in the other group. They found that keeping the platelet count above 150,000 did not diminish the odds of serious hemorrhage. On that basis, we judge that permitting the platelet count to fall to $20,000 / \mu \mathrm{l}$ (mass of $160 \mathrm{fl} / \mathrm{nl}$ ) before a transfusion to a 'stable' neonate is derived from category of evidence 3 , with a strength of evidence that must be graded low/small 'I' because of the lack of needed data. We judge that permitting the platelet count to fall to $50,000 / \mu \mathrm{l}$ (mass of $400 \mathrm{fl} / \mu \mathrm{l}$ ) before a transfusion is given to an 'unstable' neonate is derived from category of evidence $2 \mathrm{~B}$ and the strength of recommendation is moderate/small $\mathrm{C}$, principally because of the lack of sufficient studies to judge the number needed to treat or the number needed to produce an adverse outcome.

\section{Fresh-Frozen Plasma Transfusion}

\section{Should Screening Coagulation Tests Be Routinely}

Performed on VLBW Infants?

Significant hemorrhage can be a devastating occurrence during neonatal care. If severe hemorrhages (grades 3 or 4), pulmonary hemorrhage or diffuse purpura could be prevented by prophylactic frozen plasma transfusion, this would surely lead to better neurodevelopmental outcomes and lower costs of care.

One approach to reducing hemorrhage among VLBW neonates has been to perform screening coagulation tests, such as fibrinogen, PT and aPTT and, if abnormal, to administer fresh-frozen plasma with the intention of correcting the abnormalities and thereby reducing the bleeding risk. Although this is a reasonable approach, it has several inherent problems. First, normal reference intervals for these coagulation tests have been lacking for the smallest and most immature neonates [63-65], thus it has been unclear when a value is truly abnormal. Second, it is not clear under which specific conditions administering fresh-frozen plasma will reduce the risk of a serious hemorrhage $[66,67]$. Third, the total costs and risks of this approach require better definition in order to balance these against any proven benefits [67]. We judge that the evidence favors not performing routine coagulation screening tests of VLBW neonates [68-72], and that the recommendation is derived from category $2 \mathrm{~B}$ evidence and the strength of this recommendation is graded C, because of the lack of sufficient studies.

\section{Disclosure Statement}

The authors have no conflicts of interest to disclose. 


\section{References}

1 Josephson CD, Glynn SA, Kleinman SH, Blajchman MA; State-of-the Science Symposium Transfusion Medicine Committee: A multidisciplinary 'think tank': the top 10 clinical trial opportunities in transfusion medicine from the National Heart, Lung, and Blood Institute-sponsored 2009 state-of-the-science symposium. Transfusion 2011;51:828-841.

2 Kelly AM, Williamson LM: Neonatal transfusion. Early Hum Dev 2013;89:855-860.

- 3 Venkatesh V, Curley AE, Clarke P, Watts T, Stanworth SJ: Do we know when to treat neonatal thrombocytopaenia? Arch Dis Child Fetal Neonatal Ed 2013;98:F380-F382.

4 Venkatesh V, Khan R, Curley A, New H, Stanworth S: How we decide when a neonate needs a transfusion. Br J Haematol 2013;160: 421-433.

5 Sallmon H, Sola-Visner M: Clinical and research issues in neonatal anemia and thrombocytopenia. Curr Opin Pediatr 2012;24:16-22.

6 Strauss RG: Anaemia of prematurity: pathophysiology and treatment. Blood Rev 2010;24: 221-225.

7 Strauss RG: Platelet transfusions in neonates: questions and answers. Expert Rev Hematol 2010;3:7-9.

8 Sawaya GF, Guirguis-Blake J, LeFevre M, Harris R, Petitti D; U.S. Preventive Services Task Force: Update on the methods of the U.S. Preventive Services Task Force: estimating certainty and magnitude of net benefit. Ann Intern Med 2007;147:871-875.

-9 Downey CL, Bewley S: Historical perspectives on umbilical cord clamping and neonatal transition. J R Soc Med 2012;105:325-329.

10 Darwin E: Zoonomia. Dublin, Dugdale, 1801, vol 3.

11 Yao AC, Lind J: Effect of gravity on placental transfusion. Lancet 1969;2:505-508.

12 Yao AC, Lind J, Tiisala R, Michelsson K: Placental transfusion in the premature infant with observation on clinical course and outcome. Acta Paediatr Scand 1969;58:561-566.

13 Rabe H, Diaz-Rossello JL, Duley L, Dowswell T: Effect of timing of umbilical cord clamping and other strategies to influence placental transfusion at preterm birth on maternal and infant outcomes. Cochrane Database Syst Rev 2012;8:CD003248.

14 Sisson TR, Knutson S, Kendall N: The blood volume of infants. IV. Infants born by cesarean section. Am J Obstet Gynecol 1973;117: 351-357.

15 Hosono S, Mugishima H, Fujita H, Hosono A, Minato M, Okada T, Takahashi S, Harada K: Umbilical cord milking reduces the need for red cell transfusions and improves neonatal adaptation in infants born at less than 29 weeks' gestation: a randomised controlled trial. Arch Dis Child Fetal Neonatal Ed 2008; 93:F14-F19.

-16 Hosono S, Mugishima H, Fujita H, Hosono A, Okada T, Takahashi S, Masaoka N, Yamamoto $\mathrm{T}$ : Blood pressure and urine output during the first $120 \mathrm{~h}$ of life in infants born at less than 29 weeks gestation related to umbilical cord milking. Arch Dis Child Fetal Neonatal Ed 2009;94:F328-F331.

17 Freise KJ, Widness JA, Veng-Pedersen P: Erythropoietic response to endogenous erythropoietin in premature very low birth weight infants. J Pharmacol Exp Ther 2010;332:229-237.

18 Carroll PD, Nankervis CA, Iams J, Kelleher K: Umbilical cord blood as a replacement source for admission complete blood count in premature infants. J Perinatol 2012;32:97-102.

19 Hansen A, Forbes P, Buck R: Potential substitution of cord blood for infant blood in the neonatal sepsis evaluation. Biol Neonate 2005;88:12-18.

20 Herson VC, Block C, McLaughlin JC, Tetreault J, Eisenfeld LI, Krause PJ: Placental blood sampling: an aid to the diagnosis of neonatal sepsis. J Perinatol 1998;18:135-137.

-21 Polin JI, Knox I, Baumgart S, Campman E, Mennuti MT, Polin RA: Use of umbilical cord blood culture for detection of neonatal bacteremia. Obstet Gynecol 1981;57:233-237.

22 Christensen RD, Lambert DK, Baer VL, Montgomery DP, Barney CK, Coulter DM, Ilstrup S, Bennett ST: Postponing or eliminating red blood cell transfusions of very low birth weight neonates by obtaining all baseline laboratory blood tests from otherwise discarded fetal blood in the placenta. Transfusion 2011;51:253-258.

23 Bekeris LG, Tworek JA, Walsh MK, Valenstein PN: Trends in blood culture contamination: a College of American Pathologists QTracks study of 356 institutions. Arch Pathol Lab Med 2005;129:1222-1225.

24 Gonsalves WI, Cornish N, Moore M, Chen A, Varman M: Effects of volume and site of blood draw on blood culture results. J Clin Microbiol 2009;47:3482-3485.

25 Connell TG, Rele M, Cowley D, Buttery JP, Curtis N: How reliable is a negative blood culture result? Volume of blood submitted for culture in routine practice in a children's hospital. Pediatrics 2007;119:891-896.

26 American Academy of Pediatrics Subcommittee on Hyperbilirubinemia: Management of hyperbilirubinemia in the newborn infant 35 or more weeks of gestation. Pediatrics 2004;114:297-316.

27 Judd WJ: Practice guidelines for prenatal and perinatal immunohematology, revisited. Transfusion 2001;41:1445-1452.

28 Baer VL, Lambert DK, Carroll PD, Gerday E, Christensen RD: Using umbilical cord blood for the initial blood tests of VLBW neonates results in higher hemoglobin and fewer RBC transfusions. J Perinatol 2013;33:363-365.

29 Ringer SA, Richardson DK, Sacher RA, Keszler M, Churchill WH: Variations in transfusion practice in neonatal intensive care. Pediatrics 1998; 101:194-200.

30 Becquet O, Guyot D, Kuo P, et al: Respective effects of phlebotomy losses and erythropoi- etin treatment on the need for blood transfusion in very premature infants. BMC Pediatr 2013;13:176.

- 31 Rosebraugh MR, Widness JA, Nalbant D, Veng-Pedersen P: A mathematical modeling approach to quantify the role of phlebotomy losses and need for transfusions in neonatal anemia. Transfusion 2013;53:1353-1360.

- 32 Kling PJ, Sullivan TM, Leftwich ME, Roe DJ: Score for neonatal acute physiology and phlebotomy blood loss predict erythrocyte transfusions in premature infants. Arch Pediatr Adolesc Med 1997;151:27-31.

33 Valieva OA, Strandjord TP, Mayock DE, Juul SE: Effects of transfusions in extremely low birth weight infants: a retrospective study. J Pediatr 2009;155:331-337.

34 Madan A, Kumar R, Adams MM, Benitz WE, Geaghan SM, Widness JA: Reduction in red blood cell transfusions using a bedside analyzer in extremely low birth weight infants. J Perinatol 2005;25:21-25.

35 Widness JA, Madan A, Grindeanu LA, Zimmerman MB, Wong DK, Stevenson DK: Reduction in red blood cell transfusions among preterm infants: results of a randomized trial with an in-line blood gas and chemistry monitor. Pediatrics 2005;115:1299-1306.

36 Barie PS: Phlebotomy in the intensive care unit: strategies for blood conservation. Crit Care 2004;8(suppl 2):S34-S36.

- 37 Pabla L, Watkins E, Doughty HA: A study of blood loss from phlebotomy in renal medical inpatients. Transfus Med 2009;19:309-314.

38 Ohlsson A, Aher SM: Early erythropoietin for preventing red blood cell transfusion in preterm and/or low birth weight infants. Cochrane Database Syst Rev 2012;9: CD004863.

39 Aher SM, Ohlsson A: Late erythropoietin for preventing red blood cell transfusion in preterm and/or low birth weight infants. Cochrane Database Syst Rev 2014;23;4: CD004868.

40 Aher SM, Ohlsson A: Early versus late erythropoietin for preventing red blood cell transfusion in preterm and/or low birth weight infants. Cochrane Database Syst Rev 2012; 10:CD004865.

41 Donato H, Vain N, Rendo P, Vivas N, Prudent L, Larguía M, Digregorio J, Vecchiarelli C, Valverde R, García C, Subotovsky P, Solana C, Gorenstein A: Effect of early versus late administration of human recombinant erythropoietin on transfusion requirements in premature infants: results of a randomized, placebo-controlled, multicenter trial. Pediatrics 2000; 105:1066-1072.

- 42 Maier RF, Obladen M, Muller-Hansen I, Kattner E, Merz U, Arlettaz R, Groneck P, Hammer H, Kössel H, Verellen G, Stock GJ, Lacaze-Masmonteil T, Claris O, Wagner M, Matis J, Gilberg F; European Multicenter Erythropoietin Beta Study Group: Early treatment with erythropoietin beta ameliorates 
anemia and reduces transfusion requirements in infants with birth weights below $1000 \mathrm{~g}$. J Pediatr 2002;141:8-15.

43 Ohls RK, Christensen RD, Kamath-Rayne BD, Rosenberg A, Wiedmeier SE, Roohi M, Lacy CB, Lambert DK, Burnett JJ, Pruckler B, Schrader R, Lowe JR: A randomized, masked, placebocontrolled study of darbepoetin alfa in preterm infants. Pediatrics 2013;132:e119-e127.

- 44 Ohls RK, Kamath-Rayne BD, Christensen RD, Wiedmeier SE, Rosenberg A, et al: Cognitive outcomes of preterm infants randomized to darbepoetin, erythropoietin, or placebo. Pediatrics 2014;133:1023-1030.

45 Egrie JC, Browne JK: Development and characterization of novel erythropoiesis stimulating protein (NESP). Br J Cancer 2001;84 (suppl 1):3-10.

-46 Bierer R, Peceny MC, Hartenberger CH, Ohls RK: Erythropoietin concentrations and neurodevelopmental outcome in preterm infants. Pediatrics 2006;118:e635-e640.

47 McAdams RM, McPherson RJ, Mayock DE, Juul SE: Outcomes of extremely low birth weight infants given early high-dose erythropoietin. J Perinatol 2013;33:226-230.

-48 Neubauer AP, Voss W, Wachtendorf M, Jungmann T: Erythropoietin improves neurodevelopmental outcome of extremely preterm infants. Ann Neurol 2010;67:657-666.

-49 Brown MS, Eichorst D, Lala-Black B, Gonzalez R: Higher cumulative doses of erythropoietin and developmental outcomes in preterm infants. Pediatrics 2009;124:e681-e687.

50 Carr R, Kelly AM, Williamson LM: Neonatal thrombocytopenia and platelet transfusion a UK perspective. Neonatology 2015;107:DOI: 10.1159/00365163.

51 Galel SA, Fontaine MJ, Viele MK, Gonzalez L, Goodnough LT: Transfusion medicine; in Greer JP, Arber DA, Glader B, List AF, Means RT Jr, Paraskevas F, Rodgers GM (eds): Wintrobe's Clinical Hematology, ed 13. Philadelphia, Lippincott, Williams \& Wilkins, 2014, pp 556-557.

52 Sola-Visner MC: Platelets in the neonatal period: developmental differences in platelet production, function, and hemostasis and the potential impact of therapies. Hematology Am Soc Hematol Educ Program 2012;2012:506-511.

53 Christensen RD: Platelet transfusion in the neonatal intensive care unit: benefits, risks, alternatives. Neonatology 2011;100:311-318.

- 54 Cremer M, Sola-Visner M, Roll S, Josephson CD, Yilmaz Z, Bührer C, Dame C: Platelet transfusions in neonates: practices in the United States vary significantly from those in Austria, Germany, and Switzerland. Transfusion 2011;51:2634-2641.

55 Josephson CD, Su LL, Christensen RD, Hillyer CD, Castillejo MI, Emory MR, Lin Y, Hume H, Easley K, Poterjoy B, Sola-Visner M: Platelet transfusion practices among neonatologists in the United States and Canada: results of a survey. Pediatrics 2009;123:278-285.

- 56 Stanworth SJ, Clarke P, Watts T, Ballard S, Choo L, Morris T, Murphy MF, Roberts I;
Platelets and Neonatal Transfusion Study Group: Prospective, observational study of outcomes in neonates with severe thrombocytopenia. Pediatrics 2009;124:e826-e834.

57 Venkatesh V, Khan R, Curley A, New H, Stanworth S: How we decide when a neonate needs a transfusion. Br J Haematol 2013;160: 421-433.

58 Christensen RD, Paul DA, Sola-Visner MC, Baer VL: Improving platelet transfusion practices in the neonatal intensive care unit. Transfusion 2008;48:2281-2284.

59 Gerday E, Baer VL, Lambert DK, Paul DA, Sola-Visner MC, Pysher TJ, Christensen RD: Testing platelet mass versus platelet count to guide platelet transfusions in the neonatal intensive care unit. Transfusion 2009;49:20342039.

60 Zisk JL, Mackley A, Clearly G, Chang E, Christensen RD, Paul DA: Transfusing neonates based on platelet count vs. platelet mass: a randomized feasibility-pilot study. Platelets 2013, Epub ahead of print.

61 von Lindern JS, van den Bruele T, Lopriore E, Walther FJ: Thrombocytopenia in neonates and the risk of intraventricular hemorrhage: a retrospective cohort study. BMC Pediatr 2011;11:16.

62 von Lindern JS, Hulzebos CV, Bos AF, Brand A, Walther FJ, Lopriore E: Thrombocytopaenia and intraventricular haemorrhage in very premature infants: a tale of two cities. Arch Dis Child Fetal Neonatal Ed 2012;97:F348F352.

63 Ferrer-Marin F, Stanworth S, Josephson C, Sola-Visner M: Distinct differences in platelet production and function between neonates and adults: implications for platelet transfusion practice. Transfusion 2013;53:28142821.

64 Andrew M, Vegh P, Caco C, Kirpalani H, Jefferies A, Ohlsson A, Watts J, Saigal S, Milner $\mathrm{R}$, Wang E: A randomized, controlled trial of platelet transfusions in thrombocytopenic premature infants. J Pediatr 1993;123:285291.

65 Neary E, Okafor I, Al-Awaysheh F, Kirkham C, Sheehan K, Mooney C, Foran A, Corcoran JD, Ni Ainle F, Cotter M, McCallion N: Laboratory coagulation parameters in extremely premature infants born earlier than 27 gestational weeks upon admission to a neonatal intensive care unit. Neonatology 2013;104:222227.

66 Andrew M, Paes B, Milner R, Johnston M, Mitchell L, Tollefsen DM, Castle V, Powers P: Development of the human coagulation system in the healthy premature infant. Blood 1988;72:1651-1657.

67 Christensen RD, Baer VL, Lambert DK, Henry E, Ilstrup SJ, Bennett ST: Reference intervals for common coagulation tests of preterm infants. Transfusion 2014;54:627-632.

68 Catford K, Reddy C, Clarke P: Routine neonatal coagulation testing increases use of freshfrozen plasma. Transfusion 2014;54:14441445.
69 MacLennan S, Williamson LM: Risks of fresh frozen plasma and platelets. J Trauma 60:S46S50.

70 Chaudhary R, Clarke P: Current transfusion practices for platelets and fresh, frozen plasma in UK tertiary level neonatal units. Acta Paediatr 2008;97:135.

71 Motta M, Del Vecchio A, Radicioni M: Clinical use of fresh-frozen plasma and cryoprecipitate in neonatal intensive care unit. J Matern Fetal Neonatal Med 2011;24 (suppl 1):129-131.

72 Motta M, Testa M, Tripodi G, Radicioni M: Changes in neonatal transfusion practice after dissemination of neonatal recommendations. Pediatrics 2010;125:e810-e817.

73 Emmerson AJ: Role of erythropoietin in the newborn. Arch Dis Child 1993;69(3 Spec No):273-275

74 Messer J: Haddad J, Donato L, Astruc D, Matis J: Early treatment of premature infants with recombinant human erythropoietin. $\mathrm{Pe}$ diatrics 1993;92:519-523.

75 Maier RF, Obladen M, Scigalla P, Linderkamp O, Duc G, Hieronimi G, Halliday HL, Versmold HT, Moriette G, Jorch G, Verellen G, Semmekrot BA, Grauel EL, Holland BM, Wardrop C for the European Multicentre Erythropoietin Study Group: The effect of epoetin beta (recombinant human erythropoietin) on the need for transfusion in very-lowbirth-weight infants. European Multicentre Erythropoietin Study Group. N Engl J Med 1994;330:1173-1178.

76 Ohls RK, Ehrenkranz RA, Wright LL, Lemons JA, Korones SB, Stoll BJ, Stark AR, Shankaran S, Donovan EF, Close NC, Das A: Effects of early erythropoietin therapy on the transfusion requirements of preterm infants below 1250 grams birth weight: a multicenter, randomized, controlled trial. Pediatrics 2001;108:934-942.

77 Haiden N, Schwindt J, Cardona F, Berger A, Klebermass K, Wald M, Kohlhauser-Vollmuth C, Jilma B, Pollak A: Effects of a combined therapy of erythropoietin, iron, folate, and vitamin B12 on the transfusion requirements of extremely low birth weight infants. Pediatrics 2006;118:2004-2013.

-78 Birenbaum HJ, Pane MA, Helou SM, Starr KP: Comparison of a restricted transfusion schedule with erythropoietin therapy versus a restricted transfusion schedule alone in very low birth weight premature infants. South Med J 2006;99:1059-1062.

79 Khatami SF, Mamouri G, Torkaman M: Effects of early human recombinant erythropoietin therapy on the transfusion in healthy preterm infants. Indian J Pediatr 2008;75:12271230.

80 Tempera A, Stival E, Piastra M, De Luca D, Ottaviano C, Tramontozzi $\mathrm{P}$, Marconi $\mathrm{M}$, Cafforio C, Marcozzi P, Rossi N, Buffone E: Early erythropoietin influences both transfusion and ventilation need in very low birth weight infants. J Matern Fetal Neonatal Med 2011;24:1060-1064. 